\title{
Trading information for conservation: a novel use of radio broadcasting to reduce sea turtle bycatch
}

\author{
Joanna Alfaro-Shigueto, Jeffrey C. Mangel, Peter H. Dutton \\ JefFrey A. Seminoff and Brendan J. Godley
}

\begin{abstract}
Bycatch of non-target animals in small-scale fisheries poses a major threat to seabirds and marine mammals and turtles. This is also a problem for small-scale fisheries in Peru because of the magnitude of these fisheries and the important marine biodiversity in Peruvian waters. Here we describe how we implemented a novel approach to mitigate bycatch impacts on marine turtles in Peru. We used high-frequency (HF) two-way radio communication to exchange information with fishers. We sought data that would afford insights into fishing patterns and levels of turtle bycatch so that we could identify areas of high-density bycatch in real time and warn other fishers. In return we provided oceanographic and atmospheric information useful for the fishers. Radio communication also served as a platform to promote the use of safe handling and release techniques for incidentally caught animals. During the 24 months of the programme we communicated with over 200 vessels and with 200-1,400 fishers, who used primarily longlines, gillnets, jiggers, purse seiners and trawlers. Our findings suggest that HF radio communication is a useful tool (low cost and widely used by fishers, with extensive spatial coverage), helps build links with fishers that potentially reduces fishery impacts on marine turtles, and can also provide information on poorly documented fisheries and the relevant bycatch data associated with small-scale fishing practices.
\end{abstract}

Keywords Bycatch, conservation, marine turtles, Peru, radio communication, small-scale fisheries, South America

\section{Introduction}

Tisheries management is challenging (Beddington et al., 2007) in part because of miscommunications between regulators and fishers regarding regulatory processes and requirements (Jentoft, 2000; van Densen \& McCay, 2007). This can result in limited trust among stakeholders, potentially leading to failure to manage the resource

Joanna Alfaro-Shigueto* (Corresponding author), Jeffrey C. Mangel* and BRENDAN J. Godley Centre for Ecology and Conservation, University of Exeter, Cornwall Campus, Penryn, UK. E-mail jas_26@yahoo.com

Peter H. Dutton and Jeffrey A. Seminoff NOAA-National Marine Fisheries Service, Southwest Fisheries Science Center, La Jolla, California, USA

*Also at: ProDelphinus, Octavio Bernal 572-5, Lima 11, Peru

Received 7 November 2011. Revision requested 10 January 2012. Accepted 23 January 2012. effectively (Kaplan \& McCay, 2004). These problems are particularly acute in small-scale fisheries, which are typically poorly managed (Salas et al., 2007; Jacquet \& Pauly, 2008). Nonetheless, when communication is used appropriately it can strengthen fisheries practices (Hartley \& Robertson, 2008; Gutierrez et al., 2011). This has been the case with fleet communication tools used in fisheries to reduce impacts on protected species such as seabirds and turtles (Gilman et al., 2006). The use of modern communication tools to enhance conservation programmes has been found to be productive in other arenas, especially in remote geographical areas (Banks \& Burge, 2004; Kavanagh, 2008).

In Peru small-scale fisheries play an important role in provision of food and are a source of employment for $>200,000$ people (McGoodwin, 2001). Bycatch in these fisheries, however, has been shown to have an impact on threatened seabirds (Awkerman et al., 2006), marine turtles (Alfaro-Shigueto et al., 2011) and marine mammals (Mangel et al., 2010). Addressing conservation of these protected species in small-scale fisheries is difficult, partly because of the remoteness of many coastal communities (Chuenpagdee et al., 2006), hampers management and enforcement. Also, the limited educational level of many stakeholders involved in these fisheries (Berkes et al., 2001) can contribute to a poor understanding of the conservation status of threatened fauna (Van Bressem et al., 2006).

In the case of marine turtles, which are greatly affected by fisheries (Lewison \& Crowder, 2007; Peckham et al., 2007; Casale, 2011), a variety of solutions to reduce bycatch are in place or being tested in many fisheries. These approaches include technological innovation (turtle excluder devices, circle hooks, lights; Watson et al., 2005; Cox et al., 2007; Wang et al., 2010), educational programmes for fishers (Marcovaldi \& Marcovaldi, 1999), the use of incentives (Ferraro \& Gjertsen, 2009), legally non-binding measures (e.g. the Inter-American Convention for the Protection and Conservation of Sea Turtles), and fisheries closures (NMFS, 2000). For small-scale fisheries, however, solutions are not widely executed and usually implemented voluntarily as most of these fisheries are poorly regulated, with limited enforcement and lack of economic incentives (Salas et al., 2007; Jacquet \& Pauly, 2008).

Communication tools have been used as an alternative way to prevent bycatch of marine turtles and other protected marine fauna in industrial fisheries (Gilman et al., 2006; Howell et al., 2008). Fleet communication programmes within the US North Atlantic longline 
swordfish, North Pacific, Alaska trawlers and Alaska demersal longline fisheries have been shown to reduce bycatch and prevent established bycatch thresholds from being exceeded (Gilman et al., 2006). In the US Hawaiian longline fleet managers provide fishers with updated maps of sea surface temperature as a tool to help them choose fishing grounds whilst avoiding bycatch of loggerhead turtle Caretta caretta (Howell et al., 2008).

Five species of marine turtles have been recorded in the waters of Peru, primarily as foraging animals (Alfaro-Shigueto et al., 2011). Tagging, genetics and satellite tracking have demonstrated linkages with distant rookeries. Genetics of the leatherback turtle Dermochelys coriacea off Peru suggest they are from rookeries in the eastern (i.e. Mexico and Costa Rica) and western Pacific (i.e. Papua New Guinea, Indonesia and Solomon Islands; Dutton et al., in press). Satellite tracking studies (Eckert \& Sarti, 1997; Shillinger et al., 2008) have linked Peru and the Mexican and Costa Rican rookeries. A proportion of the green turtles Chelonia mydas visiting Peru originate from the Galapagos (Hays-Brown \& Brown, 1982; Seminoff et al., 2008) and Mexico (Velez-Zuazo \& Kelez, in press). Loggerhead turtles are linked to populations breeding in Australia and New Caledonia (Alfaro-Shigueto et al., 2004; Boyle et al., 2009). Tagging and genetics of olive ridley turtles Lepidochelys olivacea suggest they originate from Costa Rica, Colombia and Mexico (Zeballos \& Arias-Schereiber, 2001; VelezZuazo \& Kelez, in press). There is a paucity of information for the hawksbill turtle Eretmochelys imbricata but there may be links with continental Ecuador (Gaos et al., 2010). All these species are vulnerable to fisheries impacts (AlfaroShigueto et al., 2010a, 2011), and the effect of fisheries bycatch on some of these stocks has been detrimental (Spotila et al., 2000; Limpus \& Limpus, 2003).

Peruvian small-scale fishing vessels often conduct trips offshore for $>3$ weeks (Alfaro-Shigueto et al., 2010b). As a result fishers are on land for only short periods, preventing their participation in many conservation programmes (i.e. attending workshops or outreach talks conducted at their ports). To address this we implemented a high frequency (HF) radio communication programme that communicates with fishers at sea to provide guidelines on the use of safe release methods for incidentally captured turtles, as well as information useful to them, in exchange for voluntary reports of locations of turtle bycatch. The aim was to use the provided locations to identify potential areas of high bycatch. These locations were then reported back to fishers operating in the same areas in an attempt to reduce the impacts of their fisheries on marine turtle populations.

\section{Methods}

We broadcasted from a fixed station based at Lima $\left(12^{\circ} 30^{\prime} \mathrm{S}\right.$, $77^{\circ} 24^{\prime} \mathrm{W}$ ) using a Vertex 1700 HF radio (price range: USD
1,600-1,800). Power output was 100-125 watts. Receiving frequency was $30 \mathrm{kHz}-30 \mathrm{MHz}$ and transmission frequency was 1.6-30 MHz. We used a multiband antenna that offered flexibility in switching between bands and frequencies during communications.

We used the internet to access daily updated oceanographic data (sea surface temperature, wind direction, chlorophyll, tides and potentially dangerous events; e.g. tsunamis, rough sea conditions), using websites that offer these services without charge (e.g. Buoyweather, 2012). Local websites were also used, such as the Peruvian Coastguard Dirección de Capitanías y Puertos (DICAPI, 2012) and the Instituto del Mar del Perú (IMARPE, 2012).

Broadcasts were from 0.90 to 15.00 , local time, from January 2009 to December 2010. The number of broadcast days per month varied. During January-March 2009 we broadcasted 20 days per month, during April-July 200913 days, from August 2009 to May 20107 days, and during June-December 20108 days. Broadcasts were initiated by us on an open work frequency used daily by fishers throughout Peru and whenever fishers were interested in more information they would respond and initiate a conversation. Further into the conversation they would usually request to go into a personal frequency to provide information on marine fauna and fishing areas used.

Communications were two-way and in real time, preferably with fishing vessel captains. During each radio conversation we requested the boat name and ID, tonnage capacity, port of origin, date of departure and estimated date of arrival in home port, number of crew, fishing gear used, status of the person contacted (e.g. crew, captain), target species, fishing area used and any further information on fishing effort (type and number of hooks, number of fishing net panels) and their contact details (phone number, common radio frequency used, e-mail). We registered information on location of turtle bycatch, numbers captured, final fate (released live, discarded dead or retained for consumption), condition of capture (entangled, hooked) and species, if identified. Radio broadcasters were biologists and veterinarians, trained in handling, resuscitation and release techniques. Whenever turtle bycatch was reported we provided instructions on safe handling and release, based upon the National Marine Fisheries Service onboard observer protocols (NMFS-SEFSC, 2008). Our contact details were also shared with fishers, including name, phone number, address and e-mail.

\section{Results}

\section{Broadcasting coverage}

We obtained a total of 535 communications of which $74 \%$ were with vessels that communicated with us on multiple occasions (mean 2.3 \pm SD 2.5, range 1-22; Fig. 1). 


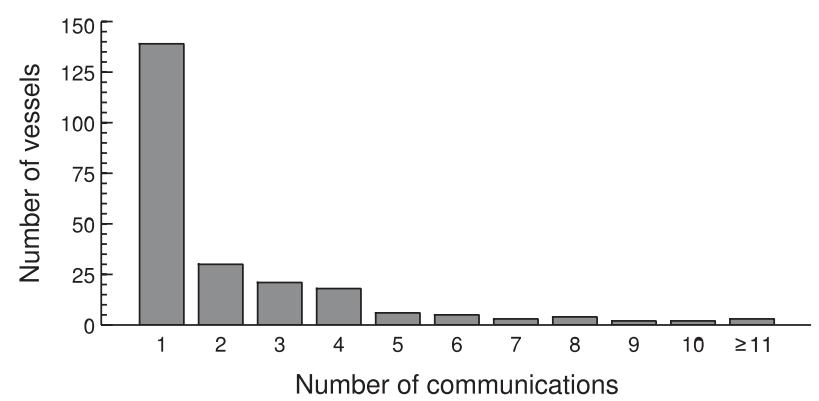

FIG. 1 Number of HF communications per fishing vessel. The total number of contacts with vessels was 535 and the greatest number of contacts with a single vessel was 22 .

The programme reached 234 small-scale fishing vessels from 18 fishing ports, from Manta in Ecuador to Iquique in Chile, giving a broadcast range of $>3,000 \mathrm{~km}$ of coastline (Fig. 3). The number of communications per port of origin was, by an order of magnitude, led by Ilo, Paita, Pucusana, Ancon, Callao and Chimbote, with others constituting much smaller proportions of contacts (Fig. 2).

\section{Contacts}

Over 239 days of communications there were no contacts with fishing vessels on only 39 days (16.3\%). The overall mean daily rate of radio contacts was $2.4 \pm$ SD 1.7 vessels (range 0-7). A total communication time of 208 hours was obtained. Mean talk time per contact was $23.8 \pm$ SD 11.9 minutes (range $3-117, n=522$ ). Considering that at least one fisher per vessel $(n=234)$ heard the conversation at least 234 fishermen were reached. However, if one also includes the number of crew on board per communication (mean $6.3 \pm \mathrm{SD} 2.3$, range 3-22, $\mathrm{n}=437$ trips) for all vessels contacted, we estimate that as many as 1,474 fishers may have been reached by the programme.

\section{Fisheries description}

In most cases we contacted the fishing captain $(89.9 \%$, $\mathrm{n}=535)$, followed by a crew member $(8.8 \%)$ and the cook (1.3\%). Most of the contacts were with longline vessels (80.4\%), followed by gillnet boats (15.0\%), jiggers targeting squid (3.4\%), purse-seiners (1.1\%) and trawlers (0.2\%).

Fishing areas reported showed that longliners operated extensively from Ecuador to Chile, and as far as 600 nautical miles offshore. Jigger boats stayed close to the coast, operating primarily from northern ports. Gillnet vessels operated mostly within and on the edge of the continental shelf and were less common towards the southern coast. The limited number of locations reported by the purse-seiners precluded further insights into the distribution of this fleet (Fig. 3).

Reported target species included dolphinfish Coryphaena hippurus (57.9\%), elasmobranchs, mostly blue

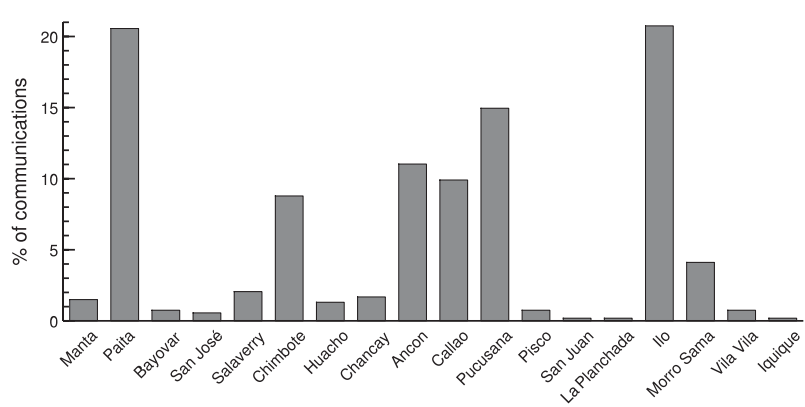

FIG. 2 Percentage of communications, of a total of 535 communications, per port, with ports (Fig. 3) listed from north (Manta) to south (Iquique).

Prionace glauca and mako sharks Isurus oxyrinchus (25.0\%), swordfish Xiphius gladias (7.0\%), Humboldt squid Dosidicus gigas (4.7\%), bonito Sarda chiliensis chiliensis (2.2\%), Patagonian toothfish Dissostichus eleginoides (1.5\%), anchoveta Engraulis ringens (0.9\%) and schooling fishes (i.e. chub mackerel Scomber japonicus, Chilean jack mackerel Trachurus murphyi; 0.5\%).

The mean reported capacity in gross tonnage (GRT) was $13.0 \pm$ SD $8.9 \mathrm{t}$ (range $4-70, \mathrm{n}=227$ vessels). Vessels of 6-15 GRT were the most common $(80.7 \%, \mathrm{n}=227$ vessels), with a minority of vessels of 30-70 GRT (6.4\%).

Because most communications were with longline vessels we obtained more detailed information for this fishing method. The type of hook used varied within the J shape hooks from number 1 to 14 (the higher the number, the smaller the size of the hook). A higher percentage of vessels used number $3(19.5 \%, \mathrm{n}=430$ trips), number $5(29.8 \%)$ and number 2 (15.8\%). The mean number of hooks reported by longline vessels was 1,680.6 \pm SD 521.7 (range 700-4,000, $\mathrm{n}=410$ trips).

\section{Turtle bycatch}

Of a total of 535 communications $44.3 \%$ of fishers reported incidental turtle captures, totalling 1,395. The majority of the bycatch was of hard-shelled turtles: green $(74.3 \%)$, loggerhead $(17.5 \%)$ and olive ridley turtles (5.7\%). Leatherback turtles comprised $2.5 \%$ of reported bycatch. Of the reported turtle bycatch $52.5 \%$ were entangled and $47.5 \%$ hooked. In most cases (97.3\%) these turtles were released alive; however, $1.9 \%$ of turtles were discarded dead and $0.7 \%$ were retained when dead and consumed as food on board.

Reported bycatch was higher during the summer and the lowest number of events was reported in spring, for all species (Table 1). Although interactions with green turtles were reported from most of the range, they appeared to be particularly common in central areas (Fig. 4). This species appeared to have a more northerly distribution in winter/spring (Table 1). A generally northerly distribution was evident for interactions with olive ridley turtles, which were also more prominent in winter/spring (Table 1, Fig. 4). 


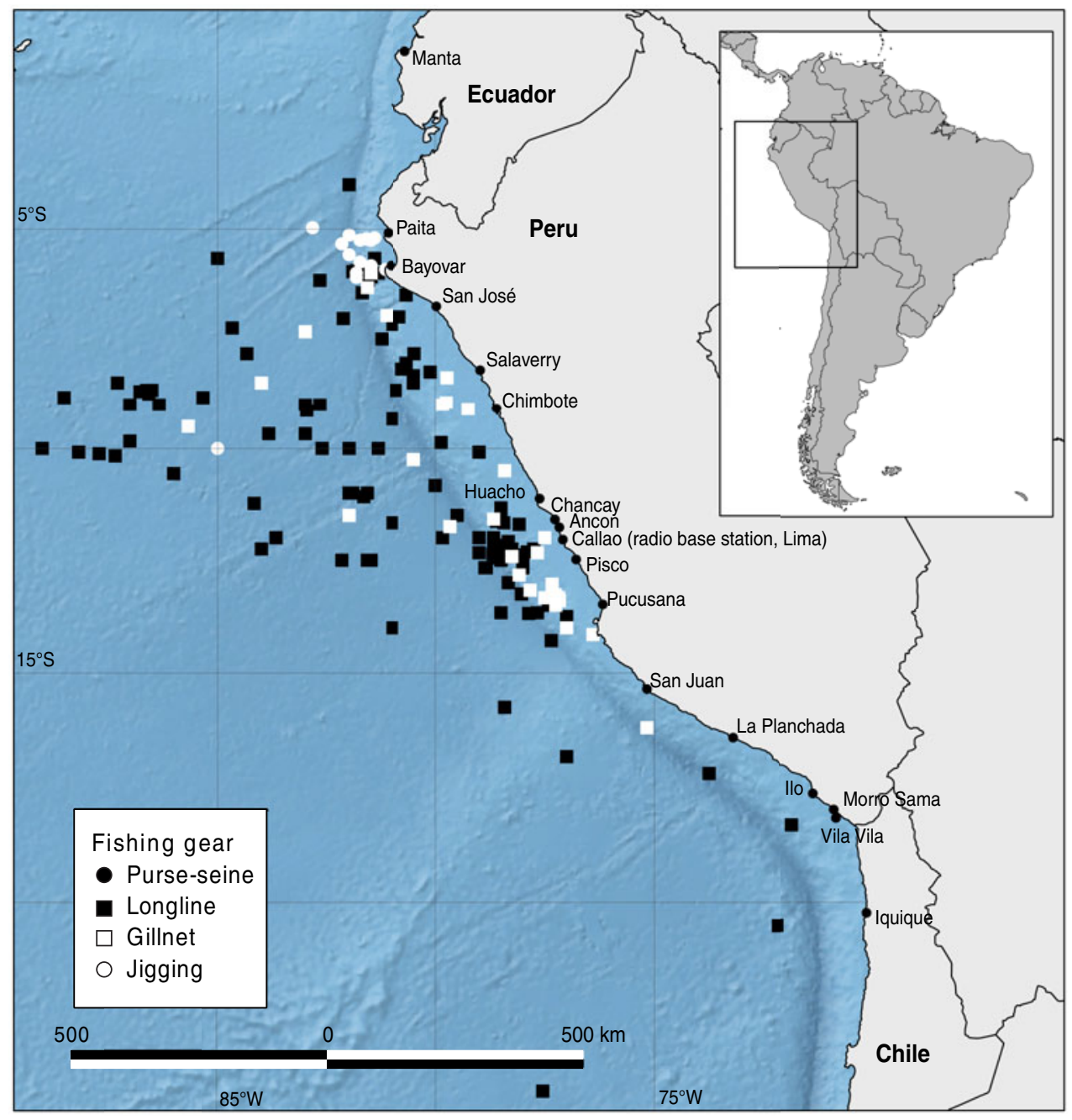

FIg. 3 Distribution of the use of fishing gear types (purseseine, longline, gillnet and jigging) used by the 234 small-scale fishing vessels with which we made radio contact, and the locations of the 18 ports of origin (from Manta in Ecuador to Iquique in Chile) of the vessels. The location of the continental shelf is indicated. The inset indicates the location of the main map in South America.
Conversely, reports of interactions with loggerhead turtles had a more southerly distribution (Table 1, Fig. 4). Although interactions with leatherback turtles were least numerous, they spanned the whole latitudinal range of the study. Most interactions with loggerhead turtles were off the continental shelf (Fig. 4).

\section{Follow-up contacts and other bycatch}

In fifty-seven communications other bycatch was reported, including Procellariform seabirds (54.4\%), cetaceans (36.8\%; dusky dolphins Lagenorhynchus obscurus, common dolphins Delphinus spp., bottlenose dolphins Tursiops truncatus, humpback whales Megaptera novaeangliae), sea lions Otaria flavescens (5.3\%), and manta rays Manta birostris and Mobula sp. (3.5\%). In 10 communications fishers reported metal identification tags found on seabirds and turtles.

We received follow-up contacts from 47 vessels, via mobile phone calls reporting bycatch events. We also received visits in Lima from four fishers interested in personally meeting programme staff and obtaining educational materials on marine turtles and the target species. Additionally, we received seven e-mails from fishers providing pictures taken with their mobile phone cameras.

\section{Radio used as a safety tool}

On four occasions we assisted vessels that were damaged or adrift. We worked as a bridge between these vessels and the Peruvian Coast Guard, local fishing association or their families, as direct contact from the vessels was not possible. Further assistance in coordinating their rescue was also provided.

\section{Discussion}

The benefits of this low-cost programme as an alternative way to engage fishers in marine conservation became quickly apparent, offering a means to mitigate the impact of fisheries on marine turtles. The radio programme covered a vast area (from Ecuador to Chile) and the real time communications with fishers offered a unique opportunity 
TABLE 1 Reported numbers, by port and quarter, of four species of turtles caught as bycatch. Q1, autumn (22 April-21 June); Q2, winter (22 July-21 September); Q3, spring (22 October-21 December); Q4, summer (22 December-21 March).

\begin{tabular}{|c|c|c|c|c|c|c|c|c|c|c|c|c|c|c|c|c|}
\hline \multirow[b]{2}{*}{ Ports $(\mathrm{N} \rightarrow \mathrm{S})$} & \multicolumn{4}{|c|}{ Chelonia mydas } & \multicolumn{4}{|c|}{ Caretta caretta } & \multicolumn{4}{|c|}{ Lepidochelys olivacea } & \multicolumn{4}{|c|}{ Dermochelys coriacea } \\
\hline & Q1 & Q2 & Q3 & Q4 & Q1 & Q2 & Q3 & Q4 & Q1 & Q2 & Q3 & Q4 & Q1 & Q2 & Q3 & Q4 \\
\hline Manta & & & & 3 & & & & & & & & 1 & & & & \\
\hline Paita & 20 & 44 & 25 & 73 & & & & & 5 & 30 & 2 & 11 & 1 & 1 & & 2 \\
\hline \multicolumn{17}{|l|}{ Bayovar } \\
\hline \multicolumn{17}{|l|}{ San José } \\
\hline Salaverry & 7 & & & 13 & & & & 1 & & & & 2 & & & & \\
\hline Chimbote & 59 & 13 & & 67 & 1 & & & 3 & 1 & & & 2 & & 1 & & 3 \\
\hline Huacho & 4 & & & & & & & & & & & & & & & \\
\hline Chancay & 3 & & & 16 & & & & & & & & & & & & \\
\hline Ancon & 6 & 17 & 13 & 262 & & 5 & & 30 & & 5 & & 10 & & & & 7 \\
\hline Callao & 17 & & 2 & 70 & 1 & & & 6 & 1 & & & & 2 & & 2 & 1 \\
\hline Pucusana & 57 & 2 & 8 & 186 & 19 & & & 26 & 2 & & & 5 & 3 & 1 & 2 & 6 \\
\hline Pisco & & & 1 & 4 & & & & & & & & & & & & \\
\hline San Juan & 8 & & & 5 & 24 & & & & & & & 2 & & & & \\
\hline La Planchada & 1 & & & & & & & & & & & & & & & \\
\hline Ilo & 12 & & & 3 & 29 & 10 & & 74 & & & & & 1 & & & 1 \\
\hline Morro Sama & 1 & & & & 3 & & & & & & & & & & & \\
\hline Vila Vila & & & & & & & & & & & & & & & & \\
\hline Iquique & & & & & 12 & & & & & & & & 1 & & & \\
\hline Total & 195 & 76 & 49 & 702 & 89 & 15 & 0 & 140 & 9 & 35 & 2 & 33 & 8 & 3 & 4 & 20 \\
\hline
\end{tabular}

to exchange information that benefited their fisheries (i.e. sea surface temperature, wind directions, tides) but also identified areas of potential high turtle bycatch, later reported back to fishers as a warning to fish with caution.

The number of small-scale fishing vessels in Peru has been estimated at c. 9,000 (Alfaro-Shigueto et al., 2011) and thus our programme reached $2.6 \%$ of this total for the country. However, the number of fishers reached through this study was possibly as many as 1,474 , highlighting the opportunity offered by this programme to engage large numbers of active fishers in conservation. The personal contacts provided by the fishers (i.e. e-mail, phone number), provided channels for further communication to be explored, especially for those with e-mail or social network accounts.

Similar efforts using communication to prevent bycatch of loggerhead turtles in high-use areas have also been undertaken in the Hawaii-based longline fleet (Howell et al., 2008). The 'Turtle watch' programme (Howell et al., 2008) consolidated information on reported bycatch, sea surface temperature and satellite telemetry data to create and distribute maps showing areas of high-use by loggerhead turtles in the North Pacific. Correspondingly, the use of communications within the US North Atlantic longline and North Atlantic and Alaska trawl fleets has been used to reduce fleet-wide bycatch of marine turtles, seabirds and certain crustaceans and fish species (Gilman et al., 2006).

The vast majority of contacts were with the small-scale longline fleet. Given the continued growth of this fishery in Peru (Alfaro-Shigueto et al., 2010b; Estrella \& Swartzman,
2010) this programme has an opportunity to work and expand with this fishery. The general characteristics of the fleet obtained from the radio programme (i.e. size of vessel, tonnage) were similar to those obtained from government records (Estrella \& Swartzman, 2010) and on-board observer programmes (Alfaro-Shigueto et al., 2010b). Fishing areas used by each of the net and longline fleets, within and off the continental shelf, respectively, were also consistent with those identified by on-board observer programmes (Alfaro-Shigueto et al., 2011). The speciesspecific spatial patterns of bycatch locations reported were also in broad concordance with those obtained by on-board observer programmes (Alfaro-Shigueto et al., 2011). Additionally, seasonality of bycatch, peaking in the summer season (December-March), concurs with other studies in the same region (Hays-Brown \& Brown, 1982; Donoso \& Dutton, 2010; Alfaro-Shigueto et al., 2011). These overlaps in the fisheries operations and fishing areas used by small-scale fisheries, as well as in species seasonality and spatial distribution, confirm the accuracy of our radio broadcast programme.

The final fates of captured turtles reported via radio indicated that the vast majority were released alive, with a minority being discarded dead or retained when dead for eating on board. Similar patterns were documented by onboard observer programmes for longline fisheries (AlfaroShigueto et al., 2011). No fisher, however, reported via radio to have retained a live turtle for consumption on board, which could have been because of uncertainty as to how such information would be used. 

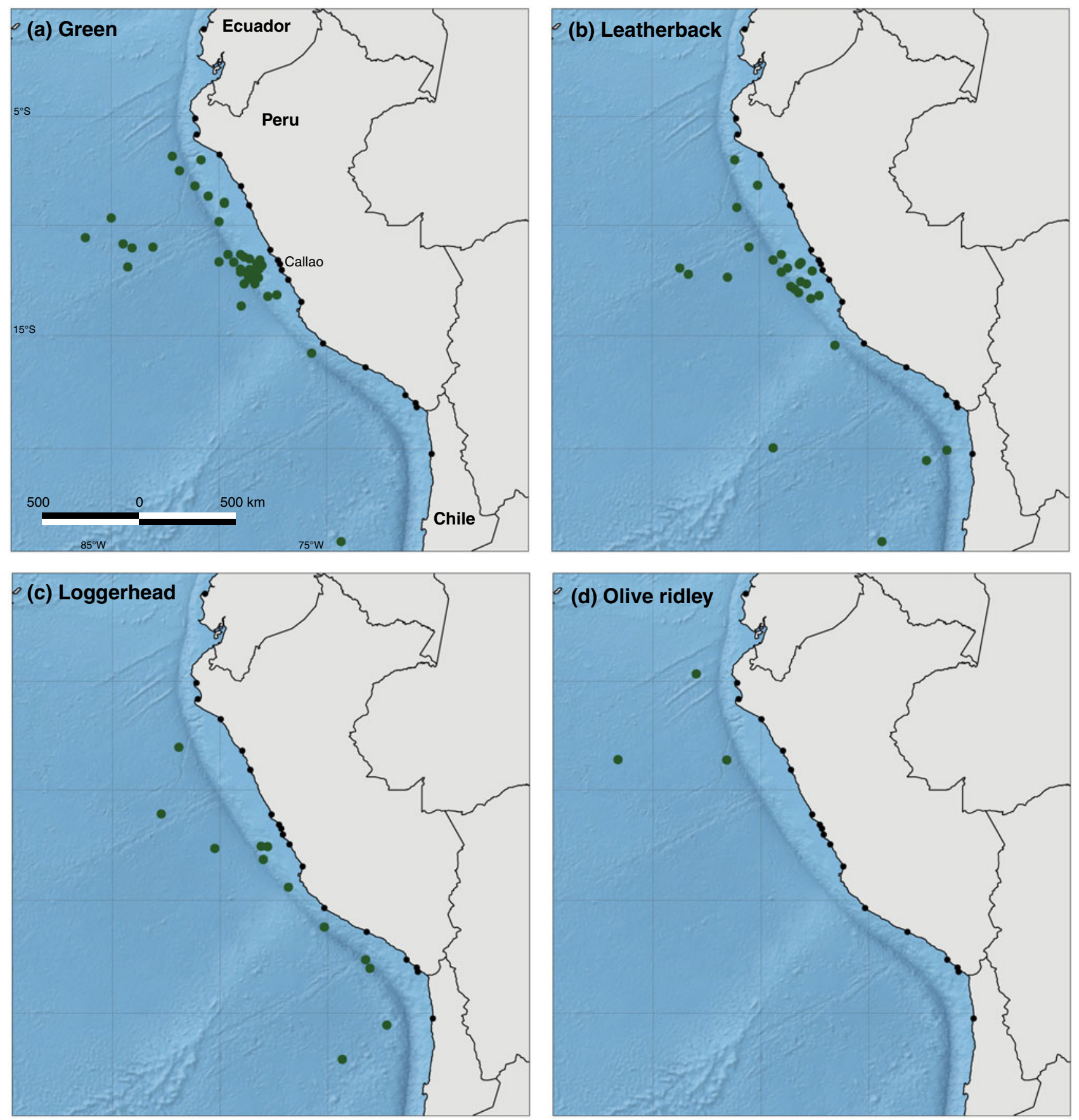

FIG. 4 Locations of interactions with (a) green Chelonia mydas $(\mathrm{n}=45)$, (b) leatherback Dermochelys coriacea $(\mathrm{n}=27)$, (c) loggerhead Caretta caretta $(n=14)$ and olive ridley marine turtles Lepidochelys olivacea $(n=3)$ reported by the small-scale fishing vessels with which we made contact. The locations of the 18 ports of origin (Fig. 3) of the fishing vessels are indicated but only Callao is labelled, for reference. The location of the continental shelf is indicated.

The radio programme offered direct benefits to the fisheries (i.e. advice on oceanographic features, warnings about dangerous events, presence of hazardous manta rays for small vessels). Use as a safety tool, in cases where vessels were adrift, was a serendipitous service provided by the programme. Considering that safety at sea is a particular problem for small-scale fisheries (FAO, 2008) the radio is a backup or alternative plan for vessels that have no other safety devices (e.g. distress radio beacons) for at-sea emergencies. The radio programme, which is still in daily operation, now also transfers to fishers information on market prices for their catch, allowing them to better time their return to port or choose a port with a better price.

One of the major advantages of the use of this radio programme included the direct, personal contact established with the main stakeholders involved in turtle 
conservation at sea, promoting an opportunity to establish a relationship of trust with individual fishermen working in remote areas. Our communications were mostly with the captain of the vessel because he is the main authority (Bureau of Labor Statistics, 2010), the one responsible for overseeing the fishing operation and the most likely to make decisions related to bycatch (i.e. release, keep for use or sale). Contacting the captains is optimal for the promotion of safe release methods for marine turtles obtained as bycatch.

Small-scale fisheries in the south-eastern Pacific are among the largest in terms of the number of fishing vessels (CPPS, 2003; Stewart et al., 2010). We used a widely available technology that, if linked with other similar stations in the region, could act as a mass-media tool. Because of the relatively low cost compared with other forms of educational campaigns and mitigation measures this approach is an alternative for situations where fisheries are highly dispersed, making traditional outreach methods cost prohibitive. Our trade of information principle could be expanded to different fleets and used to conduct rapid assessments of local fisheries, implement networking within fleets and generally encourage the active participation of fishers in marine conservation.

\section{Acknowledgements}

We thank the fishers who participated in this programme, and the ProDelphinus staff, Ortiz, Ugolini and Luna, for their help with the radio broadcasts. The study was conducted with funds received from the National Oceanographic and Atmospheric Administration, Southwest Fisheries Science Center (AB133Fo8-SE-4160), National Fish and Wildlife Foundation (2010-0107-000), the International Seafood Sustainability Foundation through the Ocean Foundation, American Bird Conservancy and the Darwin Sustainable Artisanal Fisheries Initiative in Peru. JCM and JAS are ORSAS and Exeter University scholarship awardees respectively. The article was improved greatly as a result of the Writing for Conservation Workshop organized by the Conservation Leadership Programme.

\section{References}

Alfaro-Shigueto, J., Dutton, P.H., Mangel, J. \& Vega, D. (2004) First confirmed occurrence of loggerhead turtles in Peru. Marine Turtle Newsletter, 103, 7-11.

Alfaro-Shigueto, J., Mangel, J.C., Bernedo, F., Dutton, P.H., Seminoff, J.A. \& Godley, B.J. (2011) Small-scale fisheries of Peru: a major sink for marine turtles in the Pacific. Journal of Applied Ecology, 48, 1432-1440.

Alfaro-Shigueto, J., Mangel, J.C., Caceres, C., Seminoff, J.A., Gaos, A. \& Yanez, I. (2010a) Hawksbill turtles in Peruvian coastal fisheries. Marine Turtle Newsletter, 129, 19-21.

Alfaro-Shigueto, J., Mangel, J.C., Pajuelo, M., Dutton, P.H., Seminoff, J.A. \& Godley, B.J. (2010b) Where small can have a large impact: structure and characterization of small-scale fisheries in Peru. Fisheries Research, 106, 8-17.

Awrerman, J.A., Huyvaert, K.P., Mangel, J., Shigueto, J.A. \& Anderson, D.J. (2006) Incidental and intentional catch threatens Galapagos waved albatross. Biological Conservation, 133, 483-489.

Banks, K. \& Burge, R. (2004) Mobile Phones: An Appropriate Tool for Conservation and Development? Fauna \& Flora International, Cambridge, UK.

Beddington, J.R., Agnew, D.J. \& Clark, C.W. (2007) Current problems in the management of marine fisheries. Science, 316, 1713-1716.

Berkes, F., Mahon, R., McConney, P., Pollnac, R. \& Pomeroy, R. (2001) Managing Small-Scale Fisheries: Alternative Directions and Methods. International Development Research Centre, Ottawa, Canada.

Boyle, M.C., FitzSimmons, N.N., Limpus, C.J., Kelez, S., VelezZuAzo, X. \& WAyсотт, M. (2009) Evidence for transoceanic migrations by loggerhead sea turtles in the southern Pacific Ocean. Proceedings of the Royal Society B, 276, 1993-1999.

Buoyweather (2012) Http://www.buoyweather.com [accessed 22 April 2012].

Bureau of Labor Statistics, United States Department of LABOUR (2010) Fishers and Fishing Vessels Operators. Occupational Outlook Handbook 11 Edition. Http://www.bls.gov/oco/ocos177.htm [accessed 20th August 2011].

Casale, P. (2011) Sea turtle bycatch in the Mediterranean. Fish and Fisheries, 12, 299-316.

Chuenpagdee, R., Liguori, L., Palomares, M.L.D. \& Pauly, D. (2006) Bottom-Up, Global Estimates of Small-Scale Marine Fisheries Catches Report. Fisheries Centre Research Reports, Vancouver, Canada.

Cox, T.M., Lewison, R.L., Zydelis, R., Crowder, L.B., Safina, C. \& READ, A.J. (2007) Comparing effectiveness of experimental and implemented bycatch reduction measures: the ideal and the real. Conservation Biology, 21, 1155-1164.

CPPS (Comision Permanente del Pacifico Sur) (2003) Estudio sobre el impacto socioeconomico de la pesca artesanal en los estados miembros de la Comision Permanente del Pacifico Sur. Reporte. Comision Permanente del Pacifico Sur, Guayaquil, Ecuador.

DiCapi (Direción General de Capitanías y Guardacostas Del Perú) (2012) Http://www.dicapi.mil.pe [accessed 22 April 2012].

Donoso, M. \& Dutton, P.H. (2010) Sea turtle bycatch in the Chilean pelagic longline fishery in the southeastern Pacific: opportunities for conservation. Biological Conservation, 143, 2672-2684.

Dutton, P.H., LaCasella, E.L., Alfaro-Shigueto, J. \& Donoso, M. (in press) Stock origin of leatherback (Dermochelys coriacea) foraging in the southeastern Pacific. In Proceedings of the 3oth Annual Symposium on Sea Turtle Biology and Conservation, Goa, India (eds J. Blumental, A. Panagopoulou \& A. Rees). NOAA Technical Memorandum NMFS-SEFSC. NOAA, Florida, USA.

ECKeRT, S.A. \& SARTi, L. (1997) Distant fisheries implicated in the loss of the world's largest leatherback population. Marine Turtle Newsletter, 78, 2-7.

Estrella, C. \& Swartzman, G. (2010) The Peruvian artisanal fishery: changes in patterns and distribution over time. Fisheries Research, 101, 133-145.

FAO (2008) Regional Workshop on Safety at Sea in Artisanal and Small-scale Fisheries in Latin America and the Caribbean, Paita, Peru, 2-4 July 2007. Food and Agriculture Organization Fisheries Report No. 851. 
Ferraro, P.J. \& Gjertsen, H. (2009) A global review of incentive payments for sea turtle conservation. Chelonian Conservation and Biology, 8, 48-56.

Gaos, A.R., Abreu-Grobois, F.A., Alfaro-Shigueto, J., Amorocho, D., Arauz, R., Baquero, A. et al. (2010) Signs of hope in the eastern Pacific: international collaboration reveals encouraging status for the severely depleted population of hawksbill turtles Eretmochelys imbricata. Oryx, 44, 595-601.

Gilman, E.L., Dalzell, P. \& Martin, S. (2006) Fleet communication to abate fisheries bycatch. Marine Policy, 30, 360-366.

Gutierrez, N.L., Hilborn, R. \& Defeo, O. (2011) Leadership, social capital and incentives promote successful fisheries. Nature, 470, 386-389.

Hartley, T.W. \& Robertson, R.A. (2008) Stakeholder collaboration in fisheries research: integrating knowledge among fishing leaders and science partners in northern New England. Society and Natural Resources, 22, 42-55.

Hays-Brown, C. \& Brown, W. (1982) Status of sea turtles in the southeastern Pacific: emphasis on Peru. Biology and Conservation of Sea Turtles (ed. K.A. Bjorndal), 235-240. Smithsonian Institution Press, Washington, DC, USA.

Howell, E.A., Kobayashi, D.R., Parker, D.M., Balazs, G.H. \& Polovina, J.J. (2008) TurtleWatch: a tool to aid in the bycatch reduction of loggerhead turtles Caretta caretta in the Hawaii based pelagic longline fishery. Endangered Species Research, 5 , 267-278.

imarpe (Instituto del Mar del Perú) (2012) Http://www. imarpe.gob.pe [accessed 23 April 2012].

Jacquet, J. \& Pauly, D. (2008) Funding priorities: big barriers to small-scale fisheries. Conservation Biology, 22, 832-835.

Jentoft, S. (2000) The community: a missing link of fisheries management. Marine Policy, 24, 53-59.

Kaplan, I.M. \& MCCAY, B.J. (2004) Cooperative research, comanagement and the social dimension of fisheries science and management. Marine Policy, 28, 257-258.

Kavanagh, J. (2008) Mama and Papa Bonobo. National Geographic Magazine, International Edition, 11, 33-42.

Lewison, R.L. \& Crowder, L.B. (2007) Putting longline bycatch of sea turtles into perspective. Conservation Biology, 21, 79-86.

Limpus, C.J. \& Limpus, D.J. (2003) Loggerhead Turtles in the Equatorial and Southern Pacific Ocean: a species in decline. In Loggerhead Sea Turtles (eds A.B. Bolten \& B.E. Witherington), pp. 199-209. Smithsonian Books, Washington, DC, USA.

Mangel, J.C., Alfaro-Shigueto, J., Waerebeek, K.V., Cáceres, C., Bearhop, S., Witt, M.J. \& Godley, B.J. (2010) Small cetacean captures in Peruvian artisanal fisheries: high despite protective legislation. Biological Conservation, 143, 136-143.

Marcovaldi, M.Â. \& Marcovaldi, G.G.D. (1999) Marine turtles of Brazil: the history and structure of Projeto TAMAR-IBAMA. Biological Conservation, 91, 35-41.

McGoodwin, J.R. (2001) Understanding the Cultures of Fishing Communities: a Key to Fisheries Management and Food Security. Food and Agriculture Organization, Rome, Italy.

NMFS (National Marine Fisheries Service) (2000) Fisheries off west coast states and in the western Pacific; western Pacific pelagic fisheries; Hawaii-based pelagic longline area closure 230. Federal Register Vol. 65, No. 166. US Dept. of Commerce, Washington, DC, USA.

NMFS-SEFSC (National Marine Fisheries ServiceSoutheast Fisheries Science Center) (2008) Careful Release Protocols for Sea Turtle Release with Minimal Injury. National Oceanic and Atmospheric Administration Technical Report NMFSSEFSC-580, NOAA, Florida, USA.
Peckham, S.H., Diaz, D.M., Walli, A., Ruiz, G., Crowder, L.B. \& Nichols, W.J. (2007) Small-scale fisheries bycatch jeopardizes endangered Pacific loggerhead turtles. PLoS ONE, 2, e1041.

Salas, S., Chuenpagdee, R., Seijo, J.C. \& Charles, A. (2007) Challenges in the assessment and management of small-scale fisheries in Latin America and the Caribbean. Fisheries Research, $87,5-16$.

Seminoff, J.A., Zárate, P., Coyne, M., Foley, D.G., Parker, D., Lyon, B.N. \& DutTon, P.H. (2008) Post-nesting migrations of Galápagos green turtles Chelonia mydas in relation to oceanographic conditions: integrating satellite telemetry with remotely sensed ocean data. Endangered Species Research, 4, 57-72.

Shillinger, G.L., Palacios, D.M., Bailey, H., Bograd, S.J., Swithenbank, A.M., Gaspar, P. et al. (2008) Persistent leatherback turtle migrations present opportunities for conservation. PLoS ONE Biology, 6, 9.

Spotila, J.R., Reina, R.D., Steyermark, A.C., Plotkin, P.T. \& Paladino, F.V. (2000) Pacific leatherback turtles face extinction. Nature, 405, 529-530.

Stewart, K.R., Lewison, R.L., Dunn, D.C., Bjorkland, R.H., Kelez, S., Halpin, P.N. \& Crowder, L.B. (2010) Characterizing fishing effort and spatial extent of coastal fisheries. PLOS ONE, 5 , e14451.

Van Bressem, M.-F., Alfaro-Shigueto, J., Geysen, K., Onton, K., Vega, V., Chavez-Lisambart, L. \& Van Waerebeek, K. (2006) Dolphins and children: a blueprint for marine environmental education in Peru. Applied Environmental Education and Communication, 5, 183-191.

van Densen, W.L.T. \& McCay, B.J. (2007) Improving communication from managers to fishers in Europe and the US. ICES Journal of Marine Science, 64, 811-817.

Velez-Zuazo, X. \& Kelez, S. (in press) Multi-year analysis of sea turtle bycatch by Peruvian longline fisheries: a genetic perspective. In Proceedings of the 3oth Annual Symposium on Sea Turtle Biology and Conservation, Goa, India (eds J. Blumental, A. Panagopoulou \& A. Rees). NOAA Technical Memorandum NMFS-SEFC. NOAA, Florida, USA.

Wang, J.H., Fisler, S. \& Swimmer, Y. (2010) Developing visual deterrents to reduce sea turtle bycatch in gillnet fisheries. Marine Ecology Progress Series, 408, 241-250.

Watson, J.W., Epperly, S.P., Shah, A.K. \& Foster, D.G. (2005) Fishing methods to reduce sea turtle mortality associated with pelagic longlines. Canadian Journal of Fisheries and Aquatic Sciences, 62, 965-981.

Zeballos, H. \& Arias-Schereiber, M. (2001) Informe para el taller nacional de trabajo para definir las líneas de acción prioritarias de un programa para la conservación de las tortugas marinas Perú. Instituto del Mar del Perú, La Punta, Callao, Peru.

\section{Biographical sketches}

Jonna Alfaro-Shigueto and Jeffrey Mangel direct the Peruvian NGO ProDelphinus whose work centres around monitoring and mitigating the bycatch of threatened marine fauna in small-scale fisheries. Jeffrey Seminoff is a marine ecologist studying the life history and conservation status of marine turtles throughout the Pacific. Peter Dut ton has coordinated the study of the genetics of marine turtles at the Southwest Fisheries Science Center at NOAA since 1995. BRENDAN GODLEY is a marine conservation scientist focusing on large vertebrates, especially marine turtles. 